\title{
PENGARUH RASIO LANCAR DAN RASIO HUTANG TERHADAP TINGKAT PENGEMBALIAN AKTIVA
}

\author{
Hasbi Abdul Al-Wahhab KH \\ Manajemen Keuangan Syariah, UIN Sunan Gunung Djati Bandung \\ abdhasbi98@gmail.com \\ Usep Deden Suherman \\ Manajemen Keuangan Syariah, UIN Sunan Gunung Djati Bandung \\ usepds@uinsgd.ac.id \\ Ricky Hamzah \\ Ekonomi Syariah, Universitas Suryakancana Cianjur \\ rizkyhamzah@unsur.ac.id
}

\begin{abstract}
Abstrak
Rasio yang digunakan untuk mengukur perusahaan dalam menghasilkan laba adalah tingkat pengembalian aktiva. Laba yang dihasilkan oleh perusahaan dapat diketahui melalui alat pengukuran analisis laporan keuangan salah satunya yaitu rasio lancar dan rasio hutang. Penelitian ini dilakukan dengan tujuan mengetahui dan menganalisis pengaruh dari rasio lancar dan rasio hutang terhadap tingkat pengembalian aktiva PT. Jakarta International Hotels \& Development (JIHD) baik secara parsial maupun simultan. Sehingga metode penelitian yang digunakan adalah metode deskriptif verifikatif dan pendekatan kuantitatif, dengan teknik analisis data menggunakan analisis kuantitatif yang terdiri dari uji regresi sederhana dan berganda, korelasi PPM, koefisien determinasi, dan uji hipotesis. Data penelitian bersumber dari data sekunder di mana diperoleh dari laporan keuangan tahunan dari PT. Jakarta International Hotels \& Development (JIHD). Hasil penelitian menunjukkan bahwa secara parsial hanya rasio lancar yang berpengaruh terhadap tingkat pengembalian aktiva dengan pengaruh sebesar $66 \%$, sedangkan rasio hutang tidak berpengaruh. Terakhir, secara simultan rasio lancar dan rasio hutang berpengaruh terhadap tingkat pengembalian aktiva dengan pengaruh sebesar $66.3 \%$.
\end{abstract}

Kata Kunci: Rasio Lancar, Rasio Hutang, Tingkat Pengembalian Aktiva

\section{Abstract}

The ratio used to measure the company in generating profits is the Asset Level. The profit generated by the company can be known through the measurement tools of financial statement analysis, one of which is the current ratio and debt ratio. This research was conducted with the aim of knowing and analyzing the effect of the current ratio and the ratio on the adjustment levels of PT. Jakarta International Hotels \& Development (IIHD) either partially or simultaneously. So that the research method used is desrasio lancariptive verification method and quantitative approach, with data analysis techniques using quantitative analysis consisting of simple and multiple regression tests, PPM correlation, coefficient of determination, and hypothesis testing. The research data is sourced from secondary data which is obtained from the annual financial report of PT. Jakarta International Hotels \& Development (JIHD). The results showed that partially the current ratio that affects the level of only assets with an effect of $66 \%$, while the debt ratio has no effect. Simultaneously, the current ratio and the debt ratio have an effect on the last levels with an effect of $66.3 \%$.

Keywords: Current Ratio, Debt to Equity Ratio, Return on Assets 


\section{Pendahuluan}

Saat ini, dunia sedang dilanda wabah pandemi corona virus deseases atau dikenal dengan istilah (covid 19). Hal ini memberikan dampak ke seluruh sektor kehidupan, tak terkecuali sistem ekonomi. Indonesia salah satu negara yang menjadi pusat perhatian bagi negara lain. Hal ini dapat dilihat bahwa Indonesia termasuk ke dalam 20 ekonomi utama (G20). Dalam beberapa tahun terakhir, Pemerintah Indonesia telah mengembangkan infrastruktur fisik dengan cukup pesat yang berdampak positif pada pesatnya perkembangan infrastruktur ekonomi.

Sektor tinjauan utama infrastruktur yang berkualitas salah satunya adalah bisnis pada bidang properti terutama perumahan mewah atau real estate. Bisnis properti sebagai salah satu usaha yang dipastikan tidak pernah habis karena kebutuhan akan papan atau tempat tinggal sebagai kebutuhan pokok manusia (M.Thayib dkk, 2018). Objek perusahaan yang diteliti oleh penulis di bidang properti dan real estate adalah PT. Jakarta International Hotels \& Development. Penulis tertarik meneliti objek tersebut karena merupakan salah satu dari 24 perusahaan petama yang terdaftar di Bursa Efek Indonesia (BEI) di bidang properti dan real estate. Selain itu, perusahaan ini jarang diteliti oleh mahasiswa, sehingga peneliti ingin mengetahui dan mengenalisinya lebih dalam mengenai perusahaan tersebut terkait bagaimana kinerja perusahaannya.

Salah satu informasi untuk mengetahui gambaran kinerja perusahaan di pasar modal yaitu berupa laporan keuangan. Hal ini merupakan sumber informasi yang menjadi salah satu bentuk dari pertanggungjawaban manajemen kepada pihak internal dan eksternal yang merupakan pengguna dari laporan keuangan tersebut (Linda \& Wardayani, 2019). Laporan keuangan juga inilah para investor dapat melakukan penilaian terhadap kesehatan perusahaan.

Teknik yang digunakan salah satunya analisis fundamental. Analisis fundamental adalah cara perhitungan rasio yang berasal dari informasi laporan keuangan sebuah perusahaan. Hal ini mampu memberi sebuah gambaran yang sangat jelas bagi pemegang saham tentang gambaran sebuah kinerja perusahaan. Analisis fundamental ini memiliki beberapa macam rasio keuangan yaitu rasio likuiditas, rasio solvabilitas (leverage), rasio aktivitas dan rasio profitabilitas.

Dalam mencapai keuntungan maksimal perusahaan perusahaan wajib melaksanakan berbagai aktivitas atau kegiatan selama periode tertentu, pada umumnya periode yang terjadi minimal satu kali periode. Keuntungan perusahaan pada umumnya dipergunakan oleh perusahaan dengan menggunakan tingkat pengembalian aktiva. Tingkat pengembalian aktiva merupakan kemampuan perusahaan dalam menghasilkan laba dari aktiva yang dipergunakan. Semakin besar tingkat tingkat pengembalian aktiva maka mengindikasikan semakin efisien nya perusahaan dalam menggunakan operasional nya dan menjamin berlangsungnya kehidupan perusahaan secara terus-menerus.

Tingkat pengembalian aktiva ini adalah rasio terpenting di antara profitabilitas lainnya karena semakin besar nilai tingkat pengembalian aktiva maka menunjukkan kinerja sebuah perusahaan akan semakin baik, karena return semakin besar pula. Sebaliknya, semakin kecil nilai tingkat pengembalian aktiva menunjukan kinerja perusahaan semakin kurang baik. Untuk itu Tingkat pengembalian aktiva yang maksimal tidak tertutup kemungkinan dipengaruhi oleh faktor-faktor lain seperti hutang, aktiva maupun likuiditas perusahaan. (syah, 2016).

Mengukur likuiditas sebuah perusahaan bisa dilakukan dengan berbagai cara. Salah satu rasio yang dapat digunakan adalah rasio lancar. Rasio lancar merupakan kemampuan 
perusahaan untuk memenuhi kewajiban atau utang jangka pendeknya yang jatuh tempo kurang dari satu tahun dengan menggunakan aset lancarnya. Semakin rendahnya nilai dari rasio lancar, maka akan mengindikasikan ketidakmampuan perusahaan dalam memenuhi kewajiban jangka pendeknya, sehingga hal ini dapat mempengaruhi tingkat profitabilitas perusahaan, dimana perusahaan yang tidak mampu memenuhi kewajibannya akan dikenai beban tambahan atas kewajibannya. Apabila mengukur tingkat likuiditas dengan menggunakan rasio lancar sebagai alat pengukurnya, maka tingkat likuiditas atau rasio lancar suatu perusahaan dapat dipertinggi dengan cara menggunakan utang lancar tertentu, diusahakan untuk menambah aktiva lancar dan aktiva lancar tertentu diusahakan untuk mengurangi jumlah utang lancar (PA \& Marbun, 2016).

Leverage adalah penggunaan aset dan sumber dana (sources of funds) oleh perusahaan yang memiliki biaya tetap (beban tetap) dengan maksud agar meningkatkan keuntungan potensial pemegang saham. Penggunaan hutang dalam kegiatan pendanaan perusahaan tidak hanya memberikan dampak yang baik bagi perusahaan. Jika proporsi leverage tidak diperhatikan perusahaan hal tersebut akan menyebabkan turunnya profitabilitas karena penggunaan hutang menimbulkan beban bunga yang bersifat tetap. Tidak ada perusahaan sehebat apapun yang tidak memiliki hutang. Ada perusahaan yang hutangnya kecil dan ada juga yang hutangnya besar. Untuk melihat perusahaan dalam kemampuan memenuhi kewajiban (utang) jangka panjangnya maka rasio yang dapat digunakan untuk mengukurnya adalah rasio hutang atau yang diproksikan melalui Debt to Equity Ratio (DER).

Semakin tinggi DER menunjukkan semakin besar kepercayaan dari pihak luar, hal ini sangat memungkinkan meningkatkan kinerja perusahaan, karena dengan modal yang besar maka kesempatan untuk meraih tingkat keuntungan juga besar. Dengan demikian pengaruh DER terhadap tingkat pengembalian aktiva adalah positif. Hal tersebut didukung oleh pecking order theory yang menetapkan suatu urutan keputusan pendanaan dimana para manajer pertama kali akan memilih untuk menggunakan laba ditahan, kemudian hutang, dan modal sendiri eksternal sebagai pilihan terakhir (Felicia et al., 2019).

Penulis tertarik menggunakan perhitungan DER karena semakin tinggi nilai DER menunjukan bahwa jumlah hutang yang ada pada perusahaan lebih besar daripada modalnya, maka beban yang ditanggung perusahaan untuk pemenuhan kewajiban akan semakin besar sehingga akan berdampak pada menurunnya profitabilitas perusahaan. selain itu, DER juga akan mempengaruhi tingkat pengembalian aktiva, DER yang tinggi akan berpengaruh terhadap tingkat pengembalian aktiva karena laba yang didapat akan digunakan untuk membayar kewajiban dibandingkan untuk menambah aktiva perusahaan.

Mengacu pada beberapa penelitian, yang dapat mempengaruhi Return On Assets (ROA) perusahaan hanya Current Ratio (syah, 2016). Artikel yang dilakukan oleh Andreani Caroline Barus dan Leliani mengatakan bahwa Rasio On Asset (ROA) dipengaruhi oleh Total Asset Turnover (TATO), Debt to Equity Ratio (DER) dan Ukuran Perusahaan (Barus, 2013). Menurut Harsi Romli, Aris Munandar, M. Ari Yamin dan Yohanes Susanto mengatakan bahwa Rasio On Asset (ROA) dipengaruhi oleh Net Profit Margin (NPM), Rasio lancar, Total Asset Turnover (TATO) (Romli et al., 2018).

Berdasarkan uraian yang telah dipaparkan sebelumnya, rasio lancar dan Rasio hutang terhadap Tingkat pengembalian aktiva komponen tersebut saling memiliki hubungan antara satu sama lainnya. Berikut ini data penelitian yang digunakan adalah sebagai berikut: 
Tabel 1 Data Penelitian

\begin{tabular}{|c|c|c|c|c|c|c|}
\hline \multicolumn{1}{|c|}{ Tahun } & Rasio Lancar & Ket & DER & Ket & $\begin{array}{c}\text { Data dalam persen (\%) } \\
\text { Pengembalian } \\
\text { Aktiva }\end{array}$ & Ket \\
\hline 2010 & 87.75 & & 74.00 & & 4.47 & \\
\hline 2011 & 100.00 & $\uparrow$ & 31.70 & $\downarrow$ & 1.60 & $\downarrow$ \\
\hline 2012 & 160.00 & $\uparrow$ & 31.90 & $\uparrow$ & 1.90 & $\uparrow$ \\
\hline 2013 & 320.00 & $\uparrow$ & 28.50 & $\downarrow$ & 27.30 & $\uparrow$ \\
\hline 2014 & 200.00 & $\downarrow$ & 38.40 & $\uparrow$ & 2.10 & $\downarrow$ \\
\hline 2015 & 109.50 & $\downarrow$ & 45.40 & $\uparrow$ & 1.40 & $\downarrow$ \\
\hline 2016 & 74.00 & $\downarrow$ & 38.20 & $\downarrow$ & 4.80 & $\uparrow$ \\
\hline 2017 & 82.80 & $\uparrow$ & 34.50 & $\downarrow$ & 2.90 & $\downarrow$ \\
\hline 2018 & 87.20 & $\uparrow$ & 32.20 & $\downarrow$ & 2.40 & $\downarrow$ \\
\hline 2019 & 71.30 & $\downarrow$ & 37.20 & $\uparrow$ & 2.10 & $\downarrow$ \\
\hline
\end{tabular}

Sumber: www.idx.co.id (laporan tahunan PT. JIHD)

Dari tabel di atas, terdapat penyimpangan teori yang menyatakan hubungan ketiga rasio tersebut baik secara parsial ataupun simultan. Tahun 2012 dan 2013 pada saat rasio lancar mengalami kenaikan masing-masing sebesar 160\% dan 320\% tingkat pengembalian aktiva justru mengalami kenaikan pula masing-masing sebesar 1,90\% dan 27,30\% Selain itu, ketika rasio lancar mengalami penurunan pada tahun 2014, 2015 dan 2019 masing-masing sebesar 200\%, $109,50 \%$ dan $71,30 \%$ tingkat pengembalian aktiva justru mengalami pernurunan pula sebesar $2,10 \%, 1,40 \%$ dan $2,10 \%$. Hal ini bersimpangan dengan teori yang menyatakan bahwa rasio lancar mempunyai hubungan yang berlawanan (negatif) artinya ketika rasio lancar naik maka tingkat pengembalian aktiva akan naik, begitupula sebaliknya apabila rasio lancar turun maka tingkat pengembalian aktiva juga ikut turun.

Tahun 2012 ketika DER mengalami kenaikan sebesar 31,90\% tingkat pengembalian aktiva malah mengalami kenaikan pula sebesar 1,90\%. Pada tahun 2011, 2017 dan 2018 ketika DER mengalami penurunan sebesar 31,70\%, 34,50\% dan 32,20\% tingkat pengembalian aktiva malah mengalami penurunan sebesar dan $1,60 \%, 2,90 \%$ dan 2,40\% Hal ini tentu menyimpang dari teori bahwasanya hubungan DER dan tingkat pengembalian aktiva itu berlawanan (negatif0 artinya ketika DER naik maka tingkat pengembalian aktiva turun, dan sebaliknya ketika DER turun maka tingkat pengembalian aktiva naik.

\section{Metode}

Metodologi penelitian yang dipakai dalam artikel ini yaitu menggunakan metode analisis deskriptif verifikatif dengan menggunakan pendekatan kuantitatif. Data yang dipakai yaitu data kuantitatif, maksudnya data yang bisa diukur dalam suatu skala numeric (angka) yang perhitungannya memakai metoda statistika. Penelitian deskriptif dengan pendekatan kuantitatif yaitu suatu langkah untuk menggambarkan secara sistematis tentang fakta serta hubungan antara variabel yang akan diselidiki yaitu mengumpulkan data, mengolah, menganalisis dan menginterpretasikan data ke dalam bentuk pengujian teori yang ada bukan membuat teori yang baru. Data yang diperoleh adalah data sekunder dari laporan keuangan tahunan runtun waktu (time series) dari 2010 sampai dengan 2019 PT. Jakarta International Hotels \& Development Tbk melalui website resmi JIHD dan didukung oleh studi kepustakaan dan dokumentasi. Teknik yang digunakan dalam penelitian ini adalah menggunakan Analisis Uji Asumsi Klasik, Analisis Deskriptif, Analisis Regresi, Analisis Korelasi, Analisis Koefisien Determinasi dan Analisis Uji 
Hipotesis (Uji t dan Uji F) diolah dengan perhitungan manual dan perhitungan menggunakan aplikasi IBM software Statistical Product and Service Solition (SPSS) Statitics versi 26.

\section{Hasil dan Pembahasan}

Artikel ini akan menganalisis pengaruh rasio lancar dan rasio hutang terhadap tingkat pengembalian aktiva pada PT Jakarta International Hotels \& Development Tbk periode 20102019 secara parsial dan simultan.

\subsection{Uji Asumsi Klasik}

Uji asumsi klasik akan dijabarkan dalam pembahasan di bawah ini:

a. Uji Normalitas

Uji Normalitas dilakukan untuk mengetahui apakah model regresi variabel residual berdistribusi normal. Di bawah ini uji normalitas dengan menggunakan One-Sample KolmogrovSmirnov test, sebagai berikut:

Tabel 2 Uji Normalitas

\begin{tabular}{|c|c|c|}
\hline \multicolumn{3}{|c|}{ One-Sample Kolmogorov-Smirnov Test } \\
\hline & & Unstandardized Residual \\
\hline \multicolumn{2}{|l|}{$\bar{N}$} & 10 \\
\hline \multirow[t]{2}{*}{ Normal Parameters } & Mean & ,0000000 \\
\hline & Std. Deviation & 458,09469044 \\
\hline \multirow[t]{3}{*}{ Most Extreme Differences } & Absolute & ,191 \\
\hline & Positive & ,139 \\
\hline & Negative &,- 191 \\
\hline \multicolumn{2}{|l|}{ Test Statistic } & ,191 \\
\hline \multicolumn{2}{|l|}{ Asymp. Sig. (2-tailed) } & ,200c,d \\
\hline \multicolumn{3}{|l|}{ a. Test distribution is Normal. } \\
\hline \multicolumn{3}{|c|}{ b. Calculated from data. } \\
\hline \multicolumn{3}{|c|}{ c. Lilliefors Significance Correction. } \\
\hline \multicolumn{3}{|c|}{ d. This is a lower bound of the true significance. } \\
\hline
\end{tabular}

Sumber: SPSS Windows vs 26.0 (diolah 2020)

Mengacu pada tabel di atas, diperoleh nilai signifikansi sebesar 0,200 > 0,05 yang artinya data yang diuji berdistribusi normal karena nilai signifikansi lebih besar dari 5\% sehingga uji normalitas terpenuhi.

\section{b. Uji Multikolinearitas}

Uji multikolinearitas bertujuan untuk menguji apakah model regresi sudah sesuai temukan ada korelasi antar variabel independen. Model regresi yang baik tidak akan ada korelasi antara variabel independen. Uji multikolinearitas diuji dengan menggunakan metode VIF (Variance Inflation Factor). Jika nilai tolarance $>0,10$ dengan nilai VIF $<10,00$ maka dikatakan tidak mengalami multikolinearitas. Berikut ini dengan menggunakan aplikasi SPSS.

Tabel 3 Uji Multikolinearitas

\begin{tabular}{|c|c|c|c|c|c|c|c|c|}
\hline \multicolumn{9}{|c|}{ Coefficients $^{a}$} \\
\hline \multirow{2}{*}{\multicolumn{2}{|c|}{ Model }} & \multicolumn{2}{|c|}{$\begin{array}{l}\text { Unstandardized } \\
\text { Coefficients }\end{array}$} & \multirow{2}{*}{$\begin{array}{c}\text { Standardized } \\
\text { Coefficients } \\
\text { Beta }\end{array}$} & \multirow[b]{2}{*}{$\mathrm{T}$} & \multirow[b]{2}{*}{ Sig. } & \multicolumn{2}{|c|}{$\begin{array}{l}\text { Collinearity } \\
\text { Statistics }\end{array}$} \\
\hline & & $\mathrm{B}$ & Std. Error & & & & Tolerance & VIF \\
\hline 1 & (Constant) & $-703,363$ & 721,896 & &,- 974 & ,362 & & \\
\hline & $\begin{array}{l}\text { Rasio_ } \\
\text { Lancar }\end{array}$ &, 083 &, 023 & ,831 & 3,582 & ,009 & ,897 & 1,115 \\
\hline & DER & 035 & ,139 & ,058 & 249 & ,810 & ,897 & 1,115 \\
\hline
\end{tabular}

Sumber: SPSS Windows vs 26.0 (diolah 2020) 
Mengacu pada tabel di atas, diketahui bahwa nilai tolerance 0,897 $>0,10$ dengan nilai VIF $1,115<10,00$. Dapat disimpulkan data di atas tidak terdapat multikolinearitas karena nilai tolerance lebih besar dari 0,10 dan nilai VIF lebih kecil dari 10,00 dengan kata lain model regresi tidak mengalami multikolinearitas.

\section{c. Uji Heteroskedastisitas}

Uji Heteroskedastisitas dirancang untuk menguji apakah dalam model regresi terjadi ketidaksamaan variance dari residual satu pengamatan ke pengamatan lainnya. Model regresi yang baik tidak terjadi heteroskedastisitas. Untuk menentukan ada atau tidaknya Heteroskedastisitas, peneliti menghitung dengan applikasi SPSS Windows vs 26 sebagai berikut:

\section{Grafik 7 Uji Heteroskedastisitas}

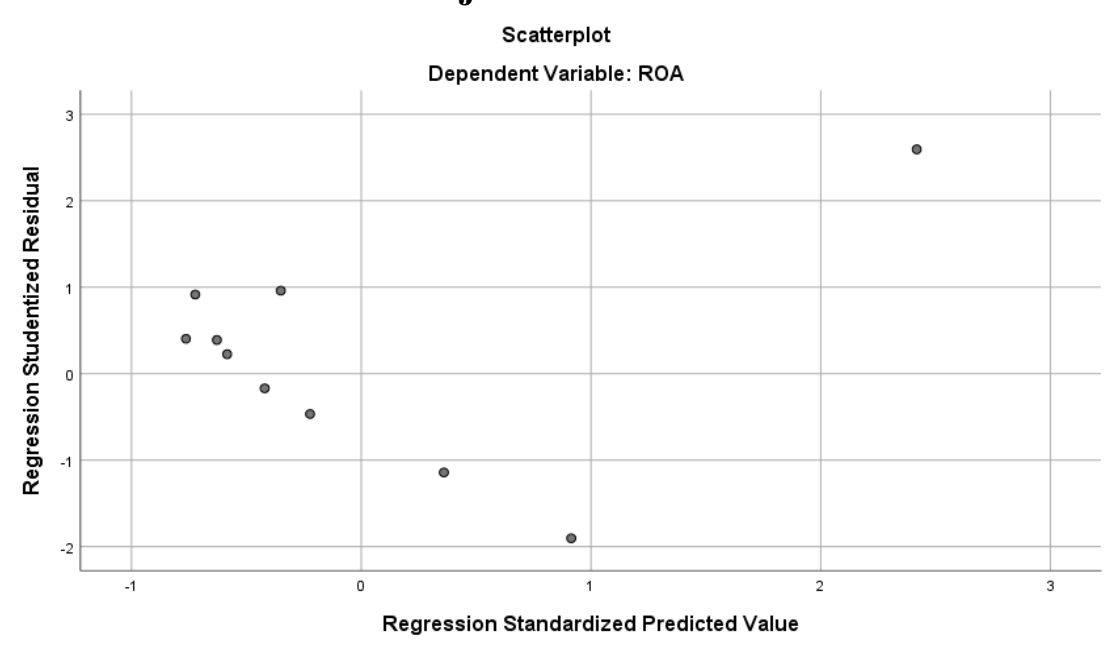

Sumber: SPSS Windows vs 26.0 (diolah 2020)

Mengacu pada grafik di atas diketahui bahwa titik-titik data menyebar di atas dan di bawah atau di sekitar angka 0, titik-titik tidak mengumpul hanya di atas atau di bawah saja, penyebaran titik-titik data tidak membentuk pola bergelombang melebar kemudian menyempit, penyebaran titik-titik tidak berpola. Dengan demikian dapat disimpulkan tidak terjadi masalah Heteroskedastisitas hingga model regresi yang baik dan ideal dapat terpenuhi.

\section{d. Uji Autokorelasi}

Uji Autokorelasi dirancang untuk menguji apakah model regresi ada korelasi antar penyalahgunaan pada periode $t$ dengan kesalahan penggunaan periode sebelumnya. Berikut adalah perhitungan uji Autokrelasi pada applikasi SPSS Windows vs 26 sebagai berikut

\section{Tabel 4 Uji Autokorelasi}

\begin{tabular}{|c|c|}
\hline \multicolumn{2}{|c|}{ Runs Test } \\
\hline & Unstandardized Residual \\
\hline Test Value $^{\mathrm{a}}$ & 133,56579 \\
\hline Cases $<$ Test Value & 5 \\
\hline Cases $>=$ Test Value & 5 \\
\hline Total Cases & 10 \\
\hline Number of Runs & 7 \\
\hline Z & ,335 \\
\hline Asymp. Sig. (2-tailed) & ,737 \\
\hline a. Median & \\
\hline
\end{tabular}

Sumber: SPSS Windows vs 26.0 (diolah 2020) 
Mengacu pada tabel di atas, diketahui signifikan memiliki nilai sebesar $0.737>0,05$. Dapat diketahui dari hasil tersebut, bahwa tidak terdapat gejala autokorelasi, sehingga analisis regresi linear dapat dilanjutkan.

\subsection{Statistik Deskriptif}

Berikut tabel perkembangan rasio lancer, rasio hutang, dan tingkat pengembalian aktiva periode 2010-2019 PT. Jakarta International Hotels \& Development Tbk.

Tabel 5 Statistik Deskriptif Rasio Lancar, Rasio hutang, dan Tingkat Pengembalian

Aktiva

\begin{tabular}{|c|c|c|c|c|c|}
\hline \multicolumn{7}{|c|}{ Desrasio lancariptive Statistics } \\
\hline & N & Minimum & Maximum & Mean & $\begin{array}{c}\text { Std. } \\
\text { Deviation }\end{array}$ \\
\hline Rasio_Lancar & 10 & 7130,00 & 32000,00 & 12925,5000 & 7862,79087 \\
\hline DER & 10 & 2850,00 & 7400,00 & 3920,0000 & 1312,43624 \\
\hline Tingkat_Pengembalian_Aktiva & 10 & 140,00 & 2730,00 & 509,7000 & 788,55480 \\
\hline Valid N (listwise) & 10 & & & & \\
\hline
\end{tabular}

Sumber: Data Input SPSS Windows vs 26.0 (diolah 2021)

Berdasarkan tabel di atas, diketahui bahwa jumlah data dalam penelitian berjumlah 10 data yang merupakan laporan keuangan yang diperoleh dari PT. Jakarta International Hotels \& Development Tbk Periode 2010 sampai 2019, berdasarkan perhitungan diatas dapat dirumuskan bahwa hasil penelitian menunjukkan variabel rasio lancar tertinggi sebesar 320 sedangkan variabel rasio lancar terendah sebesar 71,3 Secara keseluruhan rata-rata variabel rasio lancar yaitu 129,25 dengan standar deviasi 78,62. Selanjutnya hasil dari variabel DER tertinggi sebesar 74,00 sedangkan variabel DER terendah sebesar 28,50 secara keseluruhan ratarata variabel DER yaitu 39,20 dengan standar deviasi 13,12. Terakhir dari hasil penelitan menunjukkan variabel tingkat pengembalian aktiva tertinggi sebesar 27,30 sedangkan variabel tingkat pengembalian aktiva terendah sebesar 1,40 Secara keseluruhan rata-rata variabel tingkat pengembalian aktiva yaitu 5,09 dengan standar deviasi 7,88.

\subsection{Pengaruh Rasio Lancar Terhadap Tingkat Pengembalian Aktiva}

Rasio lancar merupakan rasio untuk mengukur kemampuan perusahaan dalam membayar kewajiban jangka pendek atau utang yang segera jatuh tempo pada saat ditagih secara keseluruhan. Dengan kata lain seberapa banyak aktiva lancar yang tersedia untuk menutupi kewajiban jangka pendek yang segera jatuh tempo (Hasmirati, 2019). Rasio lancar adalah kemampuan suatu perusahaan untuk memenuhi kebutuhan utang ketika jatuh tempo. Semakin tinggi Rasio lancar berarti semakin besar kemampuan perusahaan untuk memenuhi kewajiban jangka pendek. Rasio lancar yang terlalu tinggi menunjukkan kelebihan aktiva lancar yang menganggur. Jadi hal tersebut tidak baik bagi profitabilitas perusahaan karena aktiva lancar menghasilkan return yang lebih rendah dibandingkan dengan aktiva tetap (Supardi et al., 2018). Dalam pemaparan teori sebelumnya, diketahui hasil perhitungan menggunakan SPSS Windows vs 26,0 . 
Tabel 6 Analisis Regresi Pengaruh Rasio lancar Terhadap Tingkat pengembalian aktiva

\begin{tabular}{|c|c|c|c|c|c|c|}
\hline \multicolumn{7}{|c|}{ Coefficients $^{a}$} \\
\hline \multirow{2}{*}{\multicolumn{2}{|c|}{ Model }} & \multicolumn{2}{|c|}{ Unstandardized Coefficients } & $\begin{array}{c}\text { Standardized } \\
\text { Coefficients }\end{array}$ & \multirow[b]{2}{*}{$\mathrm{T}$} & \multirow[b]{2}{*}{ Sig. } \\
\hline & & $\mathrm{B}$ & Std. Error & Beta & & \\
\hline 1 & (Constant) & $-5,430$ & 3,088 & & $-1,759$ &, 117 \\
\hline & Rasio Lancar & ,081 & ,021 & 812 & 3,937 &, 004 \\
\hline
\end{tabular}
Sumber: SPSS Windows vs 26.0 (data diolah 2020)

Didapat persamaan regresi sederhana antara rasio lancar terhadap tingkat pengembalian aktiva sebagai berikut:

\section{Tingkat Pengembalian Aktiva $=\mathbf{- 5 , 4 3 0}+$ 0,081 Rasio lancar}

Dari hasil perhitungan SPSS di atas, menjelaskan bahwa antara rasio lancar dengan tingkat pengembalian aktiva menghasilkan nilai kontanta (a) sebesar $-5,430$ yang artinya apabila rasio lancar sama dengan nol (tidak ada perubahan) maka tingkat pengembalian aktiva sebesar 0,081. Nilai koefisien regresi (b) yang didapat sebesar 0,081 artinya rasio lancar berpengaruh positif terhadap tingkat pengembalian aktiva.

Selanjutnya kekuatan hubungan pengaruh Rasio lancar terhadap Tingkat pengembalian aktiva dapat dilihat pada tabel berikut ini:

Tabel 7 Analisis Korelasi Person Product Moment Pengaruh Rasio lancar Terhadap Tingkat pengembalian aktiva

\begin{tabular}{|c|c|c|c|}
\hline \multicolumn{4}{|c|}{ Correlations } \\
\hline & & $\begin{array}{c}\text { RASIO } \\
\text { LANCAR }\end{array}$ & ROA \\
\hline \multirow[t]{3}{*}{ Rasio_Lancar } & Pearson Correlation & 1 &, $812^{* *}$ \\
\hline & Sig. (2-tailed) & &, 004 \\
\hline & $\mathrm{N}$ & 10 & 10 \\
\hline \multirow[t]{3}{*}{ Tingkat_Pengembalian_Aktiva } & Pearson Correlation &, $812^{* *}$ & 1 \\
\hline & Sig. (2-tailed) &, 004 & \\
\hline & $\mathrm{N}$ & 10 & 10 \\
\hline
\end{tabular}

Sumber: SPSS Windows vs 26.0 (data diolah 2020)

Mengacu pada hasil perhitungan sebelumnya, terdapat hubungan sebesar 0,812 antara Rasio lancar terhadap Tingkat pengembalian aktiva. Dengan demikian, korelasi menunjukkan hubungan yang sangat kuat, karena nilai tersebut berada pada kriteria interval 0,80-1,00. Jadi terdapat pengaruh yang sangat kuat antara Rasio lancar terhadap Tingkat pengembalian aktiva.

Selanjutnya, kontribusi Rasio lancar terhadap Tingkat pengembalian aktiva. Dapat dilihat pada tabel di bawah ini:

Tabel 8 Analisis Koefisien Determinasi Pengaruh Rasio lancar Terhadap Tingkat pengembalian aktiva

\begin{tabular}{|c|c|c|c|c|}
\hline \multicolumn{5}{|c|}{ Model Summary ${ }^{b}$} \\
\hline Model & $\mathrm{R}$ & R Square & Adjusted R Square & Std. Error of the Estimate \\
\hline 1 & $812^{\mathrm{a}}$ &, 660 &, 617 & 48,66291 \\
\hline
\end{tabular}

a. Predictors: (Constant), Tingkat_Pengembalian_Aktiva

b. Dependent Variable: Rasio_Lancar

Sumber: SPSS Windows vs 26.0 (data diolah 2020) 
Dari tabel di atas, nilai koefisien determinasi sebesar 0,660 yang menunjukkan hubungan pengaruh antara Rasio lancar terhadap Tingkat pengembalian aktiva yaitu sebesar 0,660 atau $66 \%$, untuk sisanya sebesar 34\% dipengaruhi oleh faktor lain. Selanjutnya hasil uji hipotesis (uji t) Rasio lancar terhadap Tingkat pengembalian aktiva yaitu sebagai berikut:

Tabel 9 Analisis Uji t (Parsial) Pengaruh Rasio lancar Terhadap Tingkat pengembalian aktiva

\begin{tabular}{|c|c|c|c|c|c|c|}
\hline \multicolumn{7}{|c|}{ Coefficients $^{a}$} \\
\hline & & \multicolumn{2}{|c|}{$\begin{array}{l}\text { Unstandardized } \\
\text { Coefficients }\end{array}$} & \multirow{2}{*}{$\begin{array}{c}\text { Standardized } \\
\text { Coefficients } \\
\text { Beta }\end{array}$} & \multirow[b]{2}{*}{$\mathrm{T}$} & \multirow[b]{2}{*}{ Sig. } \\
\hline \multicolumn{2}{|c|}{ Model } & $\mathrm{B}$ & Std. Error & & & \\
\hline \multirow[t]{2}{*}{1} & (Constant) & 87,981 & 18,621 & & 4,725 &, 001 \\
\hline & Tingkat_Pengembalian_Aktiva & 8,098 & 2,057 & ,812 & 3,937 & ,004 \\
\hline
\end{tabular}

Sumber: SPSS Windows vs 26.0 (data diolah 2020)

Berdasarkan perhitungan menggunakan applikasi SPSS diperoleh nilai thitung sebesar 3,937. Sedangkan nilai $t_{\text {tabel }}$ sebesar 2,306 dan taraf signifikansi 5\% (0,05). Jadi hasil yang diperoleh yaitu $t_{\text {hitung }}>t_{\text {tabel }}$ atau 3,937 $>2,306$ dengan tingkat signifikansi 0,004 $<0,05$ dirumuskan bahwa $\mathrm{H}_{\mathrm{o}}$ di tolak dan $\mathrm{H}_{\mathrm{a}}$ diterima yang artinya secara parsial variabel rasio lancar berpengaruh positif dan signifikan terhadap tingkat pengembalian aktiva.

Hasil perhitungan yang terdapat dalam penelitian ini mendukung hasil penelitian dari Iis Cahyati (2018), dengan judul skripsi Pengarub Rasio lancar dan Rasio hutang Terhadap Tingkat pengembalian aktivas Studi Pada Sektor Logam dan Sejenisnya yang Terdaftar di Bursa Efek Indonesia Periode 2012-2016. Dalam penelitian yang dilakukan oleh Iis Cahyati menunjukkan bahwa secara parsial Rasio lancar dengan nilai t hitung sebesar $2.649773>$ t tabel yaitu 1,97208 dengan nilai signifikansi $0,0087<0,05$. Dengan demikian, dapat dirumuskan bahwa rasio lancar berpengaruh positif dan signifikan terhadap tingkat pengembalian aktiva.

Dari hasil penelitian dapat disimpulkan bahwa rasio lancar peningkatan yang diikuti dengan peningkatan tingkat pengembalian aktiva. Rasio lancar meningkat dikarenakan perusahaan mampu mengoptimalkan modal kerja untuk menjalankan kegiatan operasionalnya yang akan berdampak pada meningkatnya laba. Artinya setiap kenaikan rasio lancar maka akan di ikuti dengan kenaikan Tingkat pengembalian aktiva, begitu juga sebaliknya apabila rasio lancar mengalami penurunan maka akan diikuti dengan penurunan nilai tingkat pengembalian aktiva.

Semakin besar rasio lancar, maka menunjukkan semakin besar kemampuan perusahaan untuk memenuhi kewajiban jangka pendeknya. Hal ini menunjukkan perusahaan melakukan penempatan dana yang besar pada sisi aktiva lancar. Penempatan dana yang terlalu besar pada sisi aktiva memiliki dua efek yang sangat berlainan. Di satu sisi, likuiditas perusahaan semakin baik. Namun di sisi lain, perusahaan kehilangan kesempatan untuk mendapatkan tambahan laba, karena dana yang seharusnya digunakan untuk investasi yang menguntungkan perusahaan, dicadangkan untuk memenuhi likuiditas. Pada penelitian ini, PT. Jakarta International Hotels \& Development Tbk. memiliki rasio lancar yang tinggi yang berarti bahwa semakin produktifnya aset yang dimiliki perusahaan sehingga efektivitasnya meningkat ditandai dengan meningkatnya tingkat pengembalian aktiva.

\subsection{Pengaruh Rasio hutang Terhadap Tingkat pengembalian aktiva}

Rasio hutang merupakan perbandingan antara total hutang perusahaan terhadap total ekuitas yang dimiliki oleh perusahaan. Rasio hutang yang diproksikan melalui Debt to Equity 
Ratio (DER) ini menunjukkan kemampuan perusahaan dalam memenuhi kewajiban jangka panjang yang dimiliki perusahaan. Debt to Equity Ratio (DER) perusahaan sejatinya memiliki pengaruh terhadap profitatilitas. Semakin meningkatnya rasio hutang (beban hutang semakin besar) maka hal tersebut berdampak terhadap profitabilitas yang diperoleh perusahaan, karena sebagian digunakan untuk membayar bunga pinjaman (Prakoso \& Chabachib, 2016).

Dalam pemaparan teori di atas, hasil perhitungan menggunakan SPSS Windows vs 26,0.

Tabel 10 Analisis Regresi Pengaruh Rasio hutang Terhadap Tingkat pengembalian aktiva

\begin{tabular}{|c|c|c|c|c|c|c|}
\hline \multicolumn{7}{|c|}{ Coefficients $^{\mathrm{a}}$} \\
\hline \multirow{2}{*}{\multicolumn{2}{|c|}{ Model }} & \multicolumn{2}{|c|}{ Unstandardized Coefficients } & $\begin{array}{l}\text { Standardized } \\
\text { Coefficients }\end{array}$ & \multirow[b]{2}{*}{$\mathrm{T}$} & \multirow[b]{2}{*}{ Sig. } \\
\hline & & $\mathrm{B}$ & Std. Error & Beta & & \\
\hline \multirow[t]{2}{*}{1} & (Constant) & 10,024 & 8,544 & & 1,173 &, 274 \\
\hline & DER &,- 126 & ,208 &,- 209 &,- 605 &, 562 \\
\hline
\end{tabular}

Sumber: SPSS Windows vs 26.0 (data diolah 2020)

Didapat persamaan regresi sederhana antara Rasio hutang terhadap Tingkat pengembalian aktivasebagai berikut:

\section{Tingkat pengembalian aktiva $=10,024+-0,126$ Rasio hutang}

Dari hasil perhitungan SPSS di atas, menjelaskan bahwa antara Rasio hutang dengan Tingkat pengembalian aktiva menghasilkan nilai kontanta (a) sebesar 10,024 yang artinya apabila Rasio hutang sama dengan nol (tidak ada perubahan) maka Tingkat pengembalian aktiva sebesar -0,126. Nilai koefisien regresi (b) yang didapat sebesar -0,126 artinya Rasio hutang berpengaruh negatif terhadap Tingkat pengembalian aktiva.

Selanjutnya kekuatan hubungan pengaruh Rasio hutang terhadap Tingkat pengembalian aktiva dapat dilihat pada tabel berikut ini:

Tabel 11 Analisis Korelasi Person Product Moment Pengaruh Rasio hutang Terhadap Tingkat pengembalian aktiva

\begin{tabular}{|l|l|r|r|}
\hline \multicolumn{2}{|c|}{ Correlations } \\
\hline \multirow{4}{*}{ DER } & Pearson Correlation & DER & \multicolumn{1}{c|}{ ROA } \\
\cline { 2 - 4 } & Sig. (2-tailed) & 1 &,- 209 \\
\cline { 2 - 5 } & $\mathrm{N}$ & 10 &, 562 \\
\hline \multirow{3}{*}{ Tingkat_Pengembalian_Aktiva } & Pearson Correlation &,- 209 & 10 \\
\cline { 2 - 5 } & Sig. (2-tailed) &, 562 & 1 \\
\cline { 2 - 5 } & $\mathrm{N}$ & 10 & 10 \\
\hline
\end{tabular}

**. Correlation is significant at the 0.01 level (2-tailed).

Sumber: SPSS Windows vs 26.0 (data diolah 2020)

Mengacu pada hasil perhitungan sebelumnya, terdapat hubungan sebesar -0,209 antara Rasio hutang terhadap Tingkat pengembalian aktiva. Dengan demikian, korelasi menunjukkan hubungan yang sangat kuat, karena nilai tersebut berada pada kriteria interval $>1,00$. Jadi terdapat pengaruh yang sangat kuat antara Rasio hutang terhadap Tingkat pengembalian aktiva.

Selanjutnya, kontribusi Rasio hutang terhadap Tingkat pengembalian aktiva. dapat dilihat pada tabel di bawah ini: 
Tabel 12 Analisis Koefisien Determinasi Pengaruh Rasio hutang Terhadap Tingkat pengembalian aktiva

\begin{tabular}{|c|c|c|c|c|}
\hline \multicolumn{5}{|c|}{ Model Summaryb } \\
\hline Model & $\mathrm{R}$ & R Square & Adjusted R Square & $\begin{array}{l}\text { Std. Error of the } \\
\text { Estimate }\end{array}$ \\
\hline 1 &, $209^{a}$ &, 044 &,- 076 & 13,61248 \\
\hline \multicolumn{5}{|c|}{ a. Predictors: (Constant), Tingkat_Pengembalian_Aktiva } \\
\hline \multicolumn{5}{|c|}{ b. Dependent Variable: DER } \\
\hline
\end{tabular}

Sumber: SPSS Windows vs 26.0 (data diolah 2020)

Dari tabel di atas, nilai koefisien determinasi sebesar 0,044 yang menunjukkan hubungan pengaruh antara Rasio hutang terhadap Tingkat pengembalian aktiva yaitu sebesar 0,044 atau 4,4\%, untuk sisanya sebesar 95,6\% dipengaruhi oleh faktor lain.

Selanjutnya hasil uji hipotesis (uji t ) Rasio hutang terhadap Tingkat pengembalian aktiva yaitu sebagai berikut:

Tabel 13 Analisis uji t (parsial) Pengaruh Rasio hutang Terhadap Tingkat pengembalian aktiva

\begin{tabular}{|c|c|c|c|c|c|c|}
\hline \multicolumn{7}{|c|}{ Coefficients $^{a}$} \\
\hline \multirow{2}{*}{\multicolumn{2}{|c|}{ Model }} & \multicolumn{2}{|c|}{$\begin{array}{c}\text { Unstandardized } \\
\text { Coefficients }\end{array}$} & \multirow{2}{*}{$\begin{array}{c}\text { Standardized } \\
\text { Coefficients } \\
\text { Beta }\end{array}$} & \multirow[b]{2}{*}{$\mathrm{t}$} & \multirow[b]{2}{*}{ Sig. } \\
\hline & & $\mathrm{B}$ & Std. Error & & & \\
\hline \multirow[t]{2}{*}{1} & (Constant) & 40,975 & 5,209 & & 7,866 &, 000 \\
\hline & Tingkat_Pengembalian_Aktiva &,- 348 &, 575 &,- 209 &,- 605 &, 562 \\
\hline
\end{tabular}

Sumber: SPSS Windows vs 26.0 (data diolah 2020)

Berdasarkan perhitungan menggunakan applikasi SPSS diperoleh nilai thitung sebesar -0,605. Sedangkan nilai $\mathrm{t}_{\text {tabel }}$ sebesar 0,706 dan taraf signifikansi 5\% (0,05). Jadi hasil yang diperoleh yaitu thitung $<t_{\text {tabel }}$ atau $-0,605<0,706$ dengan tingkat signifikansi 0,562 $>0,05$ dirumuskan bahwa $\mathrm{H}_{\mathrm{o}}$ di terima dan $\mathrm{H}_{\mathrm{a}}$ ditolak yang artinya secara parsial variabel Rasio hutang berpengaruh negatif dan tidak signifikan terhadap Tingkat pengembalian aktiva.

Hasil perhitungan yang terdapat dalam penelitian di atas, mendukung hasil penelitian yang dilakukan oleh Tri Wartono (2018), jurnal dengan judul Pengaruh Rasio lancar Dan Rasio hutang Terhadap Tingkat pengembalian aktiva (Studi Pada Pt Astra International, Tbk). Dalam penelitian yang dilakukan oleh Tri Wartono menunjukkan bahwa secara parsial Rasio hutang dengan nilai $\mathrm{t}$ hitung sebesar $0,811<\mathrm{t}$ tabel yaitu 2,364262 dengan nilai signifikansi 0,444 > 0,05. Dengan demikian, dapat dirumuskan bahwa Rasio hutang berpengaruh negatif dan tidak signifikan terhadap Tingkat pengembalian aktiva.

Pada dasarnya jika perusahaan meningkatkan jumlah hutang sebagai sumber dananya hal tersebut dapat meningkatkan risiko keuangan. Namun jika perusahaan tidak dapat mengelola dana yang diperoleh dari hutang secara produktif hal tersebut dapat memberikan pengaruh negatif terhadap profitabilitas perusahaan. Sebaliknya jika hutang dikelola dengan baik dan digunakan untuk investasi produktif maka akan meningkatkan profitabilitas perusahaan (Hasmirati, 2019).

Berdasarkan uaraian diatas dapat diketahui bahwa setiap penurunan Rasio hutang tidak diikuti dengan penurunan Tingkat pengembalian aktiva, artinya setiap penurunan Rasio hutang 
berdampak baik dan terjadi peningkatan Tingkat pengembalian aktiva. Dalam hal ini menunjukkan bahwa perusahaan mampu mengelola modal dengan baik. Sehingga dapat dirumuskan bahwa, pada PT. Jakarta International Hotels \& Development Tbk. memiliki Rasio hutang yang rendah yang berarti bahwa semakin kecil modal dari pihak luar (utang) yang dimiliki perusahaan akan berdampak baik bagi perusahaan itu sendiri. Hal ini dapat dibuktikan dengan meningkatnya Tingkat pengembalian aktiva, karena hutang tersebut dikelola dengan sebaik-baiknya.

\subsection{Pengaruh Rasio lancar dan Rasio hutang terhadap Tingkat pengembalian aktiva}

Mengetahui sejauhmana kamampuan dalam mengelola modal yang disetor oleh para investor dalam rangka kemajuan perusahaan, perlu adanya pengukuran terhadap kinerja keuangan perusahaan. Berbagai aspek perlu dipertimbangkan dalam pengukuran kinerja ini, terutama harapan dari pihak-pihak yang menginvestasikan dananya. Hal ini untuk mengetahui sejauh mana perusahaan mampu mengelola dana yang berasal dari investor atau pemegang saham, dengan menilai dari seberapa besar capital gain yang dapat dihasilkan oleh perusahaan. Semakin tinggi tingkat capital gain yang diberikan oleh perusahaan kepada investor maka akan semakin tinggi nilai perusahaan yang tercermin dalam nilai saham di bursa efek (Felicia et al., 2019).

Tingkat pengembalian aktiva yaitu salah satu rasio dijadikan sebagai tolak ukur dalam kemampuan perusahaan untuk mendapatkan keuntungan yang bersumber dari tingkat aktiva tertentu. Banyak sekali yang mempengaruhi rasio ini baik memiliki pengaruh positif ataupun negatif. Secara teori variabel yang dipakai penulis rasio lancar dan rasio hutang memiliki pengaruh negatif terhadap tingkat pengembalian aktiva. Dalam pemaparan teori di atas, hasil perhitungan menggunakan SPSS Windows vs 26.0.

Tabel 14 Analisis Regresi Berganda Pengaruh Rasio lancar dan Rasio hutang terhadap

Tingkat pengembalian aktiva

\begin{tabular}{|c|c|c|c|c|c|c|c|c|}
\hline \multicolumn{9}{|c|}{ Coefficients $^{a}$} \\
\hline & & \multicolumn{2}{|c|}{$\begin{array}{l}\text { Unstandardized } \\
\text { Coefficients }\end{array}$} & \multirow{2}{*}{$\begin{array}{c}\text { Standardized } \\
\text { Coefficients } \\
\text { Beta }\end{array}$} & \multirow[b]{2}{*}{$\mathrm{T}$} & \multirow[b]{2}{*}{ Sig. } & \multicolumn{2}{|c|}{$\begin{array}{c}\text { Collinearity } \\
\text { Statistics }\end{array}$} \\
\hline \multicolumn{2}{|c|}{ Model } & $\mathrm{B}$ & Std. Error & & & & Tolerance & VIF \\
\hline \multirow[t]{3}{*}{1} & (Constant) & $-703,363$ & 721,896 & &,- 974 &, 362 & & \\
\hline & Rasio_Lancar &, 083 & ,023 & 831 & 3,582 &, 009 & ,897 & 1,115 \\
\hline & DER &, 035 & ,139 & 058 & 249 & 810 & ,897 & 1,115 \\
\hline
\end{tabular}

a. Dependent Variable: Tingkat_Pengembalian_Aktiva

Sumber: SPSS Windows vs 26.0 (data diolah 2020)

Menghasilkan persamaan sebagai berikut:

Tingkat Pengembalian Aktiva $=-703,363+0,083$ Rasio Lancar + 0,035 DER

Dari hasil perhitungan di atas, persamaan regresi linier berganda antara rasio lancar $\left(\mathrm{X}_{1}\right)$ dan DER $\left(\mathrm{X}_{2}\right)$ terhadap tingkat pengembalian aktiva $(\mathrm{Y})$ menghasilkan nilai kontanta (a) sebesar -703,363 yang artinya apabila rasio lancar dan rasio hutang sama dengan nol (tidak ada perubahan) maka tingkat pengembalian aktiva sebesar -703,363. Nilai koefisien regresi (b1) sebesar 0,083 yang berarti setiap peningkatan rasio lancar sebesar 1\%, maka akan berpengaruh peningkatan terhadap tingkat pengembalian aktiva sebesar 0,083. dan koefisien regresi $\left(\mathrm{b}_{2}\right)$ sebesar 0,035 artinya setiap peningkatan rasio hutang sebesar $1 \%$, maka akan berpengaruh 
penurunan terhadap tingkat pengembalian aktiva 0,035. Selanjutnya kekuatan hubungan pengaruh rasio lancar dan rasio hutang terhadap tingkat pengembalian aktiva dapat dilihat pada tabel berikut:

Tabel 15 Analisis Korelasi Berganda Pengaruh Rasio lancar dan Rasio hutang terhadap Tingkat pengembalian aktiva

\begin{tabular}{|c|c|c|c|c|}
\hline \multicolumn{5}{|c|}{ Model Summary ${ }^{b}$} \\
\hline Model & $\mathrm{R}$ & R Square & Adjusted R Square & Std. Error of the Estimate \\
\hline 1 &, $814^{\mathrm{a}}$ & ,663 &, 566 & 5,19431 \\
\hline \multicolumn{5}{|c|}{ a. Predictors: (Constant), DER, RASIO LANCAR } \\
\hline \multicolumn{5}{|c|}{ b. Dependent Variable: ROA } \\
\hline
\end{tabular}

Sumber: SPSS Windows vs 26.0 (data diolah 2020)

Hasil perhitungan di atas menunjukkan bahwa adanya hubungan sebesar 0,814 maka hasil perhitungan korelasi menunjukkan hubungan yang kuat karena nilai berada pada interval 0,80 1,00. Hal ini dapat dirumuskan bahwa hasil perhitungan terdapat hubungan pengaruh yang sangat kuat antara pengaruh rasio lancar dan rasio hutang terhadap tingkat pengembalian aktiva.

Selanjutnya kontribusi pengaruh rasio lancar dan rasio hutang terhadap tingkat pengembalian aktiva dapat dilihat pada tabel di bawah ini:

Tabel 16 Analisis Koefisien DeterminasiPengaruh Rasio lancar dan Rasio hutang terhadap Tingkat pengembalian aktiva

\begin{tabular}{|c|c|c|c|c|}
\hline \multicolumn{5}{|c|}{ Model Summary ${ }^{b}$} \\
\hline Model & $\mathrm{R}$ & R Square & Adjusted R Square & Std. Error of the Estimate \\
\hline 1 &, $814^{\mathrm{a}}$ & ,663 & ,566 & 5,19431 \\
\hline \multicolumn{5}{|c|}{ a. Predictors: (Constant), DER, Rasio_Lancar } \\
\hline \multicolumn{5}{|c|}{ b. Dependent Variable: Tingkat_Pengembalian_Aktiva } \\
\hline
\end{tabular}

Sumber: SPSS Windows vs 26.0 (data diolah 2020)

Dari tabel di atas, diperoleh nilai koefisien sebesar 0,663 yang menunjukkan adanya hubungan pengaruh antara rasio lancar dan rasio hutang terhadap tingkat pengembalian aktiva sebesar $66,3 \%$, dan sisanya $33,7 \%$ dipengaruhi oleh faktor lain.

Selanjutnya hasil uji hipotesis (uji F) rasio lancar dan rasio hutang terhadap tingkat pengembalian aktiva sebagai berikut:

Tabel 17 Analisis Uji F (Simultan) Pengaruh Rasio lancar dan Rasio hutang terhadap Tingkat pengembalian aktiva

\begin{tabular}{|c|c|c|c|c|c|c|}
\hline \multicolumn{7}{|c|}{ ANOVAa $^{a}$} \\
\hline \multicolumn{2}{|c|}{ Model } & Sum of Squares & Df & Mean Square & $\mathrm{F}$ & Sig. \\
\hline \multirow[t]{3}{*}{1} & Regression & 3707711,391 & 2 & 1853855,696 & 6,871 &, $022^{\mathrm{b}}$ \\
\hline & Residual & 1888656,709 & 7 & 269808,101 & & \\
\hline & Total & 5596368,100 & 9 & & & \\
\hline \multicolumn{7}{|c|}{ a. Dependent Variable: Tingkat_Pengembalian_Aktiva } \\
\hline \multicolumn{7}{|c|}{ b. Predictors: (Constant), DER, Rasio_Lancar } \\
\hline
\end{tabular}

Sumber: SPSS Windows vs 26.0 (data diolah 2020) 
Hasil perhitungan analisis signifikansi simultan menggunakan applikasi SPSS diperoleh

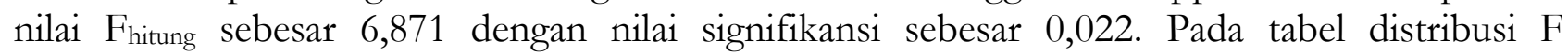
diperoleh nilai sebesar 4,74 dengan taraf signifikansi $5 \%$ atau 0,05 . Maka $F_{\text {hitung }}>F_{\text {tabel }}$ atau $6,871<4,74$ dengan tingkat signifikansi $0,022<0,05$ artinya $\mathrm{H}_{\mathrm{o}}$ ditolak dan $\mathrm{H}_{\mathrm{a}}$ diterima. rasio lancar dan rasio hutang secara simultan berpengaruh positif dan signifikan terhadap tingkat pengembalian aktiva.

Secara teori alat ukur utama perusahaan dalam kegiatan investasi yang di gunakan oleh para investor adalah rasio profitabilitas, semakin tinggi rasio profitabilitas suatu perusahaan semakin tinggi pula nilai suatu perusahaan, dengan tingginya nilai suatu perusahaan menjadi daya tarik investor untuk berinvestasi dan pada akhirnya tertuang pada kenaikan ROA (Dian Indah Sari, 2020).

Hasil perhitungan yang terdapat dalam penelitian di atas, mendukung hasil penelitian yang dilakukan oleh Iis Cahyati (2018) dan Yayu Mayang Gustia (2020. Sehingga hal ini, tidak sesuai dengan teori yang ada dimana teori menyatakan rasio lancar dan rasio hutang terhadap tingkat pengembalian aktiva memiliki pengaruh negatif. Selanjutnya, dirumuskan bahwa pada PT. Jakarta International Hotels \& Development Tbk. Jika nilai rasio lancar dan rasio hutang mengalami penurunan maka tingkat pengembalian aktiva akan turun. Begitupula sebaliknya, jika rasio lancar dan rasio hutang mengalami kenaikan maka tingkat pengembalian aktiva akan naik hal ini akan berdampak pada profitabilitas perusahaan.

\section{Kesimpulan}

Mengacu pada pembahasan yang telah diuraikan sebelumnya, disimpulkan bahwa secara parsial rasio lancar memiliki pengaruh yang sangat kuat terhadap tingkat pengembalian aktiva sebesar $66 \%$. Berbanding terbalik dengan rasio hutang terhadap tingkat pengembalian aktiva yang secara parsial memiliki pengaruh yang lemah sebesar 4,4\%. Namun, secara simultan rasio lancar dan rasio hutang memiliki pengaruh yang sangat kuat terhadap tingkat pengembalian aktiva sebesar 66,3\%. Hal ini menunjukan bahwa rasio lancar dan rasio hutang berkontribusi sebesar 66,3\% terhadap tingkat pengembalian aktiva pada PT. Jakarta International Hotels \& Development Tbk. Implikasi dari penelitian ini, PT. Jakarta International Hotels \& Development Tbk untuk memperhatikan kinerja keuangannya, terutama dilihat dari rasio likuiditas dan laverage perusahaan. Tingkat Rasio lancar yang semakin tinggi dapat meningkatkan keuntungan perusahaan dan menarik minat investor untuk memberikan modalnya kepada perusahaan, yang dimana modal tersebut dapat digunakan sebagai investasi dalam upaya meningkatkan keuntungan. Semakin tinggi rasio hutang, semakin besar resiko dan beban perusahaan terhadap pihak luar (kreditur) yang akan membuat perusahaan merugi, tetapi apabila perusahaan dapat menggunakannya secara maksimal maka hutang tersebut dapat meningkatkan keuntungan.

\section{Referensi}

Barus, A. (2013). Analisis Faktor-Faktor yang Mempengaruhi Profitabilitas pada Perusahaan Manufaktur yang Terdaftar di Bursa Efek Indonesia. JWEM Jurnal Wira Ekonomi Mikroskil), 3(2), 111-121.

Dian Indah Sari. (2020). Pengaruh Rasio lancar Dan Rasio hutang Terhadap Return. Jurnal Riset Akuntansi Dan Keuangan Dewantara, 4(1), 66-77. ISSN (online) 2581-2777 \& ISSN (print) 2581-2696

Felicia, F., Ariyanti, D., Titi, T., Velycia, V., \& Rajagukguk, R. H. (2019). Pengaruh Rasio lancar, Debt To Asset Ratio, Dan Perputaran Modal Kerja Terhadap Tingkat pengembalian aktiva 
Pada Perusahaan Sektor Industri Barang Komsumsi Yang Terdaftar Di Bursa Efek Indonesia Tahun $2013-2017 . \quad J u r n a l$ Profita, $12(2), \quad 330$. https://doi.org/10.22441/profita.2019.v12.02.011

Hasmirati. (2019). Pengaruh Rasio lancar Dan Rasio hutang Terhadap Tingkat pengembalian aktivas Pada Perusahaan Manufaktur Yang Terdaftar Di Bursa Efek Indonesia. Qfinance Calculation Toolkit, 17(01), 32-41. https://doi.org/10.5040/9781472920294.0035

Linda, N., \& Wardayani. (2019). Pengantar Akutansi -web version. March.

PA, M., \& Marbun, D. (2016). Pengaruh Rasio lancar Dan Rasio hutang Terhadap Tingkat pengembalian aktivas. Widyakala Journal, 3, 23. https://doi.org/10.36262/widyakala.v3i0.21

Prakoso, P. G. R., \& Chabachib, M. (2016). Analisis Pengaruh Rasio lancar, Size, Rasio hutang, dan Total Asset Turnover terhadap Dividend Yield dengan Tingkat pengembalian aktiva sebagai variabel Intervening. Diponegoro Journal of Marketing, 5(2), 2337-3814.

Romli, H., Munandar, A., Yamin, A., \& Susanto, Y. (2018). Faktor-faktor yang Mempengaruhi Tingkat pengembalian aktiva Perusahaan Sektor Perkebunan yang terdaftar di Bursa Efek Indonesia Tahun 2011-2016. Jurnal Manajemen Dan Bisnis Sriwijaya, 15(4), 208-220. https://doi.org/10.29259/jmbs.v15i4.5723

Supardi, H., H. Suratno, H. S., \& Suyanto, S. (2018). Pengaruh Rasio lancar, Debt To Asset Ratio, Total Asset Turnover Dan Inflasi Terhadap Tingkat pengembalian aktiva. JLAFE Jurnal Ilmiah Akuntansi Fakultas Ekonomi), 2(2), 16-27. https://doi.org/10.34204/jiafe.v2i2.541

syah, F. (2016). Analisis Hutang, Aktiva, Likuiditas yang Mempengaruhi Tingkat pengembalian aktiva pada Sektor Hotel Restoran dan Pariwisata di Bursa Efek Indonesia. Jurnal Manajemen Dan Keuangan Unsam, 5(1), 489-495.

Thayib, dkk. (2018). Pengaruh Rasio lancar, Debt To Asset Ratio, Rasio hutang Dan Total Asset Turnover Terhadap Tingkat pengembalian aktivas Pada Perusahaan Properti Dan Real Estate Di Bursa Efek Indonesia. Jurnal Akuntanika, Vol. 4 , No. 2, 1-26. 